\title{
Efecto de la adición mineral cal- zeolita sobre la resistencia a la compresión y la durabilidad de un hormigón
}

\section{Effect of lime- zeolite binder on compression strength and durability properties of concrete}

\author{
Juan José D opico M ontes de 0 ca*1, José Fernando Martirena Hernandez*, Alberto López Rodríguez**, Raúl González López*
}

* Universidad Central Marta Abreu de las Villas. CUBA

** Empresa Prefabricado Industrial Villa Clara. CU BA

Resumen

Fecha de recepción: 22/ 05/2009 Fecha de aceptación: 30/ 06/2009 PAG. $181-194$

\begin{abstract}
La práctica internacional reporta una creciente utilización de los hormigones de altas resistencias, con excelentes resultados en la durabilidad, relacionado con la obtención de una matriz cementicia muy densa, a partir del empleo de altos volúmenes de adiciones minerales muy finas, tales como las cenizas volantes, la microsílice, el metacaolín y otros materiales. Para los países emergentes, entre los cuales se ubica Cuba, el uso de estas adiciones puzolánicas resultan una solución relativamente costosa, dado los altos precios de importación de estos materiales puzolánicos, de ahí la utilidad de usar las fuentes nacionales de puzolanas disponibles de probada reactividad, como sustitutas parciales de los contenidos de Cemento Pórtland O rdinario (CPO) en las mezclas de hormigón, sin que se vean afectadas significativamente sus propiedades. El presente trabajo muestra la influencia del nivel de sustitución de los contenidos de Cemento Pórtland por adición mineral cal- puzolana, en combinación con superplastificante, en el comportamiento de la resistencia a la compresión y la durabilidad de un hormigón. Varios niveles de sustitución de CPO son evaluados, utilizando toba zeolítica como puzolana. Los resultados obtenidos corroboran la posibilidad del reemplazo de altos volúmenes de CPO por aglomerante cal-zeolita, sin que se afecten la resistencia a compresión requerida y su comportamiento ante la acción del ingreso del ion cloruro y la carbonatación.
\end{abstract}

Palabras Clave: Materiales cementicios suplementarios, resistencia a la compresión, adición cal- puzolana, cloruros, carbonatación; zeolita

Abstract

The international construction practice reports a remarkable use and development of high performance concretes, with excellent results in the durability properties, associated with a very dense cement matrix, defined from the use of high volumes of very fine minerals additions, such as, fly ash, silica fume, metakaolín and other fine powders. For the developing countries, among others Cuba, the use of these pozzolanic additions are relatively expensive, given for the high import prices of these pozzolanic materials, thus, the utility of using the national available pozzolanic sources with proven reactivity, as a partial substitute of the $\mathrm{O}$ rdinary Portland Cement (OPC) contents in the concrete mixtures without its properties are affected. The present paper shows the results of the study on the influence of substitution level of $O$ rdinary Portland Cement contents by lime - pozzolan binder in combination with chemical admixture, in the behavior of the compression strength and the durability properties of a concrete. Several levels of OPC substitution are evaluated, using zeolite as pozzolan. The results obtained prove the possibility to carry out the partial replacement of high volumes of O PC by lime - zeolite binder, without affecting the values of compression strength required and their behavior before action of the chloride ion penetration and the carbonation.

Keywords: Supplementary cementitius materials; compression strength; lime - pozzolan binder; chloride ion; carbonatation; zeolite

\section{Introducción}

La incidencia de las emisiones de la producción de cemento Pórtland en el calentamiento global, así como las continuas y crecientes intervenciones de reparación y reconstrucción en que se ven envueltas las estructuras de hormigón, como resultado de incorrectos diseños, deficiente construcción e insuficientes programas de mantenimiento, atraen cada vez mas la

\section{Introduction}

The incidence of Ordinary Portland Cement (OPC) production emissions in global warming, the continuous and increasing interventions for repairing and reconstructing concrete structures, as well as the result of wrong designs, deficient construction and insufficient maintenance programs, call the attention of specialists

\footnotetext{
${ }^{1}$ Autor de correspondencia / Corresponding author: E-mail: dopico@uclv.edu.cu
} 
atención de especialistas y gobiernos, en el apremiante tema de la vida útil de las edificaciones, todo lo cual resulta un proceso muy costoso no sólo desde el punto de vista económico, sino también desde el punto de vista ecológico. Aitcin (2000); (Bentur y Mitchel, 2008).

Las medidas necesarias a tomar para disminuir esencialmente la agresividad al medio ambiente, deberán contemplar durante la producción del cemento, la mejora de la eficiencia del proceso, minimizando los consumos de combustibles fósiles e incrementando el uso de extensores del clinker, tales como los materiales cementicios suplementarios (MCS). El uso de los MCS, incorporados durante la producción del cemento Pórtland ó durante el proceso de fabricación del hormigón, han demostrado no solo ser efectivos en la reducción de las emisiones, sino también en el mejoramiento reológico de las mezclas, en la disminución del calor de hidratación y la porosidad capilar, en el mejoramiento de las resistencias mecánicas, incluso con notables reducciones del contenido de cemento Pórtland, así como en la durabilidad de las estructuras de hormigón armado. Martirena (2004); (Scrivener y Kirkpatrick, 2008).

Las adiciones puzolánicas se utilizan como material cementicio suplementario, siempre que la puzolana sea reactiva. La contribución de los productos de reacción puzolánicos están asociados a la cantidad de $\mathrm{Ca}(\mathrm{OH})_{2}$ producido durante la reacción de hidratación del cemento, a la finura del material, así como al tipo y tiempo de curado durante las primeras edades. Para sustituciones CPO en masa en el orden del $50 \%$ ó más, la contribución principal del material puzolánico se verifica más como filler inerte, en cambio, si la puzolana de alta finura se añade a la masa de hormigón conjuntamente con hidróxido de calcio (adición calpuzolana), el suministro de cal a la mezcla fresca contribuiría a que mayores cantidades de puzolana pueda reaccionar, por lo que el potencial de productos de reacción podría incrementarse. (Mira et al., 2001); Martirena (2004).

La presencia del hidróxido de calcio adicional además, incrementaría la concentración de iones $\mathrm{Ca}^{2+}$ y $\mathrm{OH}^{-}$en la solución y con ello aceleraría el comienzo de la reacción puzolánica desde el principio. Por otro lado, la utilización de la puzolana en combinación con la cal, de finura similar a la del cemento pórtland, conduciría a la reducción del peligro de descalcificación en el hormigón, aun para grandes volúmenes de sustitución, a partir de la elevación del pH en el agua de poros, que impediría la protección pasiva del refuerzo. and governments, in relation to the compelling subject of buildings service life; this results in an expensive process, not only from the economic but also from the ecological point of view Aitcin (2000); Bentur and Mitchel (2008).

The necessary measures that should be taken in order to essentially decrease the aggressiveness towards the environment during cement production should consider the improvement of the process efficiency, minimizing mineral fuels consumptions and increasing the use of clinker expanders, such as supplementary cementing materials (SCM 's). The use of SCM's, added during the Portland cement production or during the concrete production process, has demonstrated not only to be effective in reducing emissions but also to improve mixtures rheological characteristics, to decrease the hydration temperature and porosity, to improve mechanic strength, even with strong reductions in the Portland cement content, as well as to improve reinforced concrete durability of structures Martirena (2004); Scrivener and Kirkpatrick, 2008)

Pozzolan additions are used as SCM, provided that the pozzolan is reactive. The contribution of pozzolanic reaction products is associated with: the amount of $\mathrm{Ca}(\mathrm{OH}) 2$ produced during the cement hydration reaction, the material fineness, as well as the type and period of curing during the first ages. For O PC substitutions in mass by approximately the $50 \%$ or more, the main contribution of the pozzolanic material is better verified as inert filler, than if high fineness pozzolan is added to the concrete mass together with the calcium hydroxide (lime-pozzolan addition), the lime addition to the fresh mixture would contribute to a reaction of greater amount of pozzolan, so the potential of the reaction products may be increased (Mira et al.,2001; M artirena, 2004).

Moreover, the additional calcium hydroxide presence would increase the concentration of $\mathrm{Ca}^{2+}$ and $\mathrm{OH}$ - ions in the solution and, with this, it would accelerate the starting of the pozzolanic reaction from the beginning. From other point of view, the employment of pozzolan mixed with lime, of similar fineness to that of the $O P C$, will reduce the risk of concrete decalcification, even for large substitution volumes, starting by the $\mathrm{pH}$ rising of the water contained in pores, which would prevent the reinforcement passive protection. 
(Mira et al 2001); (Sebaibi et al, 2004); (Brouwers y Radix, 2005); (Shi et al, 2005); (Jatuphon et al, 2005). De forma similar, la adición mineral cal-puzolana contribuiría en la complementación de la distribución granulométrica de los finos, pudiendo el hidróxido de calcio llegar a ocupar los espacios vacíos entre los granos de cemento y eventualmente la puzolana de alta finura, ocupar los diminutos espacios existentes entre pequeños granos del agregado fino. Este principio se aplica en la obtención de hormigones autocompactantes, y de altas resistencias, logrando excelentes resultados en las propiedades mecánicas y durabilidad, además de reducir notablemente el índice de consumo del CPO. Bornemann (2002); Martirena (2004); (Jatuphon et al., 2005).

El presente trabajo muestra la influencia del nivel de sustitución de los contenidos de Cemento Pórtland por una adición mineral cal-puzolana, en combinación con superplastificante, en el comportamiento del hormigón fresco, la resistencia a compresión y la durabilidad de un hormigón, evaluando varios niveles de sustitución, hasta formular el posible reemplazo de altos volúmenes de CPO por Adición Cal- Zeolita (ACZ), sin afectar de forma significativa la resistencia a compresión del hormigón, la penetración del ion cloruro y el fenómeno de la carbonatación.

\section{Desarrollo y discusión}

\subsection{Materiales}

El cemento Pórtland responde a la denominación P- 350, (Tipo I), elaborado por cementera Carlos Marx provincia Cienfuegos. La Tabla 2.1 muestra sus características principales.
(Mira et al., 2001; Sebaibi et al., 2004; Brouwers and Radix, 2005; Shi et al., 2005; and Jatuphon et al., 2005). Similarly, the lime-pozzolan mineral addition will contribute to complement the fines grading distribution; in this manner, the calcium hydroxide is able to fill the voids among cement grains and, eventually, the highly fine pozzolan may fill the very small spaces present among the small grains of the fine aggregate. This principle is applied to the mix design of self-compacting concretes and high strength concretes, obtaining excellent results in mechanics properties and durability, in addition to remarkably reduce the consumption index of the OPC (Bornemann, 2002; Martirena, 2004; Jatuphon et al., 2005).

This paper shows the influence of replacement of OPC contents by a lime-pozzolan mineral addition, combined with superplasticizer, on fresh concrete behavior, compressive strength, and durability of concrete. This is evaluated at different replacement levels, until reaching the maximum possible replacement level of O PC by the addition of lime-zeolite (LZA), without significantly affecting the concrete compressive strength, the chloride ion penetration and the carbonation phenomenon.

\section{Development and discussion}

\subsection{Materials}

The Portland cement responds to the denomination P- 350 (Type I), manufactured by the Carlos Marx Cement Plant, in the Province of Cienfuegos. Table 2.1 shows the main characteristics of this type of cement.

Tabla 2.1 Ensayos Físicos al Cemento Table 2.1 Cement Physical Tests

\begin{tabular}{||l|c||}
\hline \multicolumn{2}{||c||}{ Ensayos Físico-M ecánicos Cemento/Cement Physical-M echanical Tests } \\
\hline Peso Específico (g/cm³)/Specific weight $\left(\mathrm{g} / \mathrm{cm}^{3}\right)$ & 3.15 \\
\hline Finura (\% retenido en el Tamiz \# 170)/Fineness (\% retained on sieve \#170) & 2.34 \\
\hline Superficie Especifica Blaine (cm²/g)/Blaine specific surface (cm²/g) & 2974 \\
\hline Tiempo de fraguado inicial (minutos)//nitial setting time (minutes) & 165 \\
\hline Tiempo de fraguado final (horas)/Final setting time (hours) & 4.1 \\
\hline Consistencia normal (\%)/N ormal consistency (\%) & 25 \\
\hline Resistencia Flexo-tracción (7 días) M Pa/Bending tension strength (7 days) M Pa & 6.1 \\
\hline Resistencia Flexo-tracción (28 días) M Pa/Bending tension strength (28 days) M Pa & 7.5 \\
\hline Resistencia Compresión (7 días) M Pa/Compressive strength (7 days) M Pa & 28.2 \\
\hline Resistencia Compresión (28 días) M Pa/Compressive strength (28 days) M Pa & 39.1 \\
\hline \hline
\end{tabular}


Los resultados de los ensayos físicos realizados, indican cumplimiento de las especificaciones del cemento utilizado establecidas en la NC 95 / 2001. "Cemento Pórtland. Especificaciones".

El hidróxido de calcio es suministrado en bolsas de papel de $22 \mathrm{~kg}$, producidas por la Empresa Azucarera Pepito Tey, Cienfuegos; protegidas durante el trabajo experimental en bolsas de plástico para limitar la carbonatación durante el periodo de ensayos. Su peso específico es 2,46 , con $7656 \mathrm{~cm}^{2} / \mathrm{g}$ de superficie específica Blaine y un $72 \%$ de cal reactiva.

Como fuente de puzolana fue utilizada una toba zeolítica, obtenida durante el proceso de molienda, en la planta La Tasajera, Ranchuelo, denominada Zeomicro, de 2.29 de peso específico. La Tabla 2.2 muestra la composición química del hidrato de cal y la toba zeolítica obtenidas por Fluorescencia de Rayos - X.
The physical tests results show the cement specifications compliance with Cuban standard NC 95 / 2001on Portland Cement. Specifications.

Calcium hydroxide (Lime) is sold in $22 \mathrm{~kg}$ paper bags, manufactured by Empresa Azucarera Pepito Tey, Cienfuegos. During the tests period, these bags were protected with plastic bags in order to limit carbonation. Calcium hydroxide specific weight was 2.46 , with a Blaine specific surface of $7656 \mathrm{~cm}^{2} / \mathrm{g}$ and a $72 \%$ content of reactive lime.

A zeolitic tufa was used as pozzolan source, which was obtained during the milling process, in La Tasajera Plant, Ranchuelo; it is named Zeomicro and has a specific weight of 2.29. Table 2.2 shows lime and zeolitic tufa chemical compositions, which were obtained by $\mathrm{X}$ rays fluorescence spectrometer.

Tabla 2.2 Composición química Cal y Zeolita Table 2.2 Lime and Zeolite Chemical Composition

\begin{tabular}{||l|c|c|c|c|c|c|c|c||}
\hline \multicolumn{7}{||c||}{ Composición Química (\% peso)/Chemical Composition (\% weight) } \\
\hline Material & $\mathrm{SiO}_{2}$ & $\mathrm{Fe}_{2} \mathrm{O}_{3}$ & $\mathrm{Al}_{2} \mathrm{O}_{3}$ & $\mathrm{CaO}$ & $\mathrm{MgO}$ & $\mathrm{K}_{2} \mathrm{O}$ & $\mathrm{Na}_{2} \mathrm{O}$ & $\mathrm{SO}_{3}$ \\
\hline Cal/Lime & 0.884 & 0.299 & 0.341 & 97.416 & 0.588 & -- & -- & 0.473 \\
\hline Zeolita/Zeolite & 74.682 & 2.867 & 12.697 & 4.488 & 0.526 & 1.283 & 2.904 & 0.031 \\
\hline
\end{tabular}

Según la ASTM C 618- 03 la puzolana empleada clasifica como puzolana tipo $\mathrm{F}$ por contener más de $70 \%$ de los óxidos principales $\mathrm{SiO}_{2}+\mathrm{Fe}_{3} \mathrm{O}_{3}+\mathrm{Al}_{2} \mathrm{O}_{3}$. La Figura 2.1 muestra el comportamiento granulométrico de los materiales cementicios utilizados.
According to ASTM C 618- 03, the pozzolan used classifies as pozzolan type $F$, since it contains more than a $70 \%$ of the main oxides $\mathrm{SiO}_{2}+\mathrm{Fe}_{2} \mathrm{O}_{3}+\mathrm{Al}_{2} \mathrm{O}_{3}$. Figure 2.1 shows the grading behaviour of the cementitious materials used.

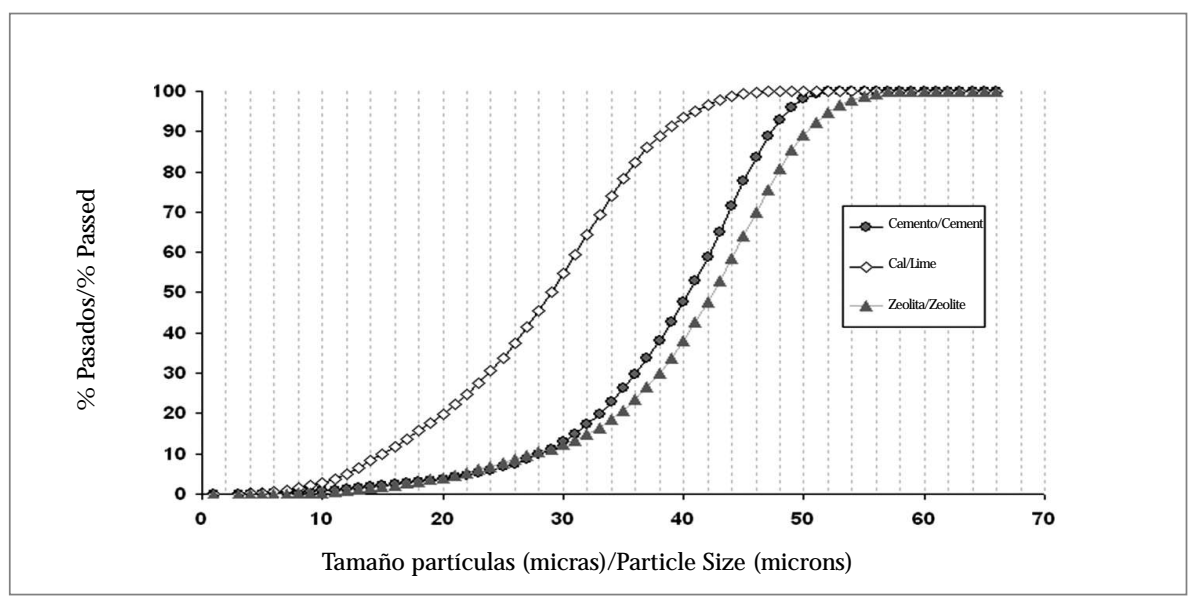

Figura 2.1 Distribuciones Granulométricas de sumatorias de cada aglomerante (Granulómetro Láser Malvern Mastersizer) Figure 2.1 Grading Distributions of Each Binder Summatory (Laser Particles Size Analyser M alvern Mastersizer) 
Los agregados grueso y fino utilizados proceden de la trituración de rocas calizas, obtenidos en la cantera "Mariano Pérez", El Purio. Su composición química muestra contenidos de $\mathrm{CaCO}_{3}$ superior al $90 \%$, y contenidos de $\mathrm{SiO}_{2}$ inferiores al $5 \%$. Como árido grueso fue trabajada una piedra de tamaño máximo $9.72 \mathrm{~mm}$, fracción (10-5) mm (Granito). Las características físicas de los áridos se detallan en las Tablas 2.3 y 2.4 .
The coarse and fine aggregates used come from crushed limestone rocks, obtained in the "Mariano Pérez" Pit, in El Purio. The chemical composition shows a $\mathrm{CaCO}_{3}$ content over $90 \%$, and $\mathrm{SiO} 2$ content less than $5 \%$. As coarse aggregate, a stone of maximum size $9.72 \mathrm{~mm}$, with a fraction of (10-5) $\mathrm{mm}$ (Granite) was employed. Aggregates physical characteristics of are detailed in Tables 2.3 and 2.4 .

Tabla 2.3 Características físicas de los áridos empleados Table 2.3 Physical Characteristics of Aggregates

\begin{tabular}{||l|c|c||}
\hline Ensayos físicos/Physical Tests & Arena/Fine Aggregate & Piedra/Coarse Aggregates \\
\hline $\begin{array}{l}\text { Material mas fino Tamiz 200 (\%) } \\
\text { Material finer than sieve 200 (\%) }\end{array}$ & 3 & 0.68 \\
\hline $\begin{array}{l}\text { Particulas planas y alargadas (\%) } \\
\text { Flat and extended particles }(\%)\end{array}$ & 0 & 0 \\
\hline $\begin{array}{l}\text { Terrones de arcilla } \\
\text { Clay clods }(\%)\end{array}$ & 0 & 0 \\
\hline $\begin{array}{l}\text { Peso específico saturado }\left(\mathrm{g} / \mathrm{cm}^{3}\right) \\
\text { Saturated specific weight }\left(\mathrm{g} / \mathrm{cm}^{3}\right)\end{array}$ & 2.6 & 2.56 \\
\hline $\begin{array}{l}\text { Masa volumétrica suelta }\left(\mathrm{kg} / \mathrm{m}^{3}\right) \\
\text { Bulk volumetric mass }\left(\mathrm{kg} / \mathrm{m}^{3}\right)\end{array}$ & 1434 & 1398 \\
\hline $\begin{array}{l}\text { Masa volumétrica compactada }\left(\mathrm{kg} / \mathrm{m}^{3}\right) \\
\text { Compacted volumetric mass }\left(\mathrm{kg} / \mathrm{m}^{3}\right)\end{array}$ & 1638 & 1487 \\
\hline
\end{tabular}

Tabla 2.4 Distribución granulométrica de los áridos empleados Table 2.4 Grading Distribution of Aggregates

\begin{tabular}{||l|c|c|c|c|c|c|c|c||}
\hline \multirow{2}{*}{ Agregado/Aggregates } & \multicolumn{7}{|c||}{ Tamices/Sieves (mm) } \\
\cline { 2 - 10 } & 12.7 & 9.52 & 4.76 & 2.38 & 1.19 & 0.59 & 0.295 & 0.149 \\
\hline Arena/Fine Aggregate & 100 & 100 & 99 & 79 & 51 & 24 & 12 & 4 \\
\hline Piedra/Coarse Aggregate & 100 & 93 & 34 & 6 & 1 & 0 & 0 & 0 \\
\hline
\end{tabular}

Los ensayos físicos realizados, indican cumplimiento de las especificaciones de los áridos utilizados, establecidas en la NC- 251 del 2005, "Áridos para hormigones hidráulicos, Requisitos".

Como aditivo químico fue utilizado MAPEFLUID N 200, superplastificante de moderada acción retardante, reductor de agua, Tipo F según la ASTM C 494. Consumo $(0,5-1,5) \mathrm{kg}$ por cada $100 \mathrm{~kg}$ de cemento $(0,4-1,25) \mathrm{I}$, 1,2 de Peso Específico.

\subsection{Plan Experimental}

Para evaluar la influencia de la adición mineral cal- zeolita en el comportamiento de la resistencia a la compresión y la durabilidad, se siguió el siguiente plan experimental, fundamentado en la utilización de la propuesta de corrección de mezclas con adiciones minerales que a continuación se relaciona: Martirena (2004).

1. Dosificación Mezcla Control del hormigón, con superplastificante y sin adición mineral, utilizando
The physical tests indicate that aggregates specifications comply with the Cuban standard NC$251 / 2005$, on Aggregates for Hydraulic Concretes, Requirements.

MAPEFLUID N200 was used as chemical admixture. It is a superplaticizer of moderate retarding action, water reducing admixture, Type $\mathrm{F}$ according to ASTM C 494. Consumption (0.5-1.5)\% of cement weight (0.4- 1.25) I, 1.2 of Specific Weight.

\subsection{Experimental Plan}

In order to evaluate the influence of lime-zeolite mineral addition in the compressive strength behaviour and durability of a concrete, the following experimental program was executed, based on the employment of the proposed idea of correcting the mixtures composition using mineral additions (Martirena, 2004), as follows:

1. Concrete Control Mix proportioning, with superplasticizer and without mineral addition, using 
método de diseño de mezclas 0 'Reilly, a partir de las materias primas disponibles y las propiedades del hormigón fresco requeridas, precisando la consistencia y trabajabilidad adecuada, acorde a la tecnología empleada y los parámetros de resistencia exigida a los 28 días 0 'Reilly (1990). Determinación experimental de proporción árido fino: árido grueso y de la dosificación del superplastificante, a partir del ensayo de fluidez en pastas por el ensayo de Cono de Marsh, según NC- 461 del 2006 "D eterminación de la fluidez de lechadas de cemento Pórtland empleando el embudo Marsh" (Etapa I)

2. Fabricación de mezclas experimentales, para diferentes valores de sustitución en masa, donde la cantidad de cemento definido en la M ezcla Control es reemplazado gradualmente por una masa similar de Adición CalZeolita (ACZ) y el agua es añadida hasta conseguir la consistencia exigida. Se establece el limite de sustitución del CPO/ACZ a partir del análisis de los valores de resistencia a compresión obtenidos y con ello la determinación del volumen de pasta $\left(\mathrm{V}_{\text {pasta }}\right)$ (Etapa II)

3. Fabricación de mezclas experimentales para diferentes niveles de sustitución ( $\beta$ ) en volumen de $C P O / A C Z$, donde la cantidad de CPO es variada en volumen por $A C Z$, manteniendo constante el $V_{\text {pasta. }}$ D eterminación límite de sustitución de CPO /ACZ a partir de evaluar los valores de resistencia a la compresión del hormigón. (Etapa III).

4. Realización ensayos de durabilidad en mezclas experimentales de la Etapa III. Definición límite de sustitución de CPO /ACZ a partir de evaluar los criterios de durabilidad.

Mezclas experimentales preparadas para similar trabajabilidad, utilizando hormigonera de acción gravitacional de 150 litros en el mezclado, proporción $47 \%$ de arena y $53 \%$ de piedra y $1.2 \%$ de superplastificante. Uso de probetas cilíndricas de 150 $\mathrm{mm} \times 300 \mathrm{~mm}$ para los ensayos de resistencia a la compresión y probetas cilíndricas de $10 \mathrm{~cm}$. $20 \mathrm{~cm}$. para los ensayos de durabilidad. Curado de probetas sumergidas en agua hasta el momento del ensayo. Probetas para los ensayos de durabilidad mantenidas expuestas bajo la acción del intemperismo, partir de los 60 días. Volumen de pasta calculado teniendo en cuenta los volúmenes aportados en cada mezcla por el cemento, la cal, la zeolita, el agua y el superplastificante. the 0 'Reilly design method of proportioning mixtures, employing available raw materials and the required properties for fresh concrete, specifying the appropriate consistency and workability, according to the technology used and the strength parameters required at 28 days, 0 'Reilly, (1990). Experimental determination of fine aggregate proportioning: coarse aggregate and superplasticizer proportioning, starting from the flow test in pastes using the Marsh Cone Test, according to NC- 461/2006 on Flow Determination of Portland Cement Grout Using the Marsh Cone, Step I.

2. Experimental mixtures manufacturing, for different mass replacement values, where the amount of OPC defined in the Control Mix is gradually replaced by a similar mass of the Lime-Zeolite Addition (LZA) and water is added until obtaining the required consistency. The substitution limit of O PC/LZA is established from the analysis of the compressive strength values obtained, and with them the paste volume determination $\left(V_{\text {paste }}\right)$, Step II.

3. Manufacturing of experimental mixture for different substitution levels $\beta$ ) in O PC/LZA volume, where the amount of $O P C$ is changed in volume by LZA, maintaining $V_{\text {paste }}$ constant. OPC/LZA limit determination from evaluation of concrete compressive strength values, Step III.

4. Practice of durability tests in experimental mixtures of Step III. O PC/ LZA Substitution Limit Determination starting from the evaluation of durability criteria.

Experimental mixtures prepared for similar workability, using a gravitational concrete mixer of 150 litres capacity, and a mixture proportioning of $47 \%$ sand, $53 \%$ stones and $1.2 \%$ of superplasticizer. Cylinder specimens of $300 \mathrm{~mm} \times 150 \mathrm{~mm}$ were used for compressive strength tests and cylinder specimens of 200 $\mathrm{mm}$. x $100 \mathrm{~mm}$. were used for durability tests. Specimens were water-cured until tested. Specimens for durability tests were exposed to environment, after 60 days of curing. The paste volume was calculated considering the volumes proportioned, in each mixture, by the cement, lime, zeolite, water and superplasticizer. 


\subsubsection{Mezcla Control}

La Mezcla Control, sin adición mineral y con superplastificante MAPEFLUID N200, diseñada para obtener $30.0 \mathrm{MPa}$ de resistencia a la compresión a los 28 días, relación a/c 0.4, dos por ciento de contenido de aire y $12 \pm 1 \mathrm{~cm}$. de asentamiento medidos por el cono de Abrams, a utilizar en la producción de elementos de hormigón, que requieren tamaño máximo del agregado grueso $9.52 \mathrm{~mm}$. La Tabla 2.5 muestra la dosificación gravimétrica utilizada.

\subsubsection{Control Mix}

The Control Mix, without mineral addition and with the MAPEFLUID N200 superplasticizer, was designed to obtain a compressive strength of $30.0 \mathrm{MPa}$ at 28 days, $\mathrm{w} / \mathrm{c}$ ratio of 0.4 , two percent of air content and $12 \pm 1$ $\mathrm{cm}$. of slump measured by the slump test, to be used in the manufacturing of concrete elements, that required a $9.52 \mathrm{~mm}$ maximum size of the coarse aggregate. Table 2.5 shows the mixture design used.

Tabla 2.5 Dosificación Mezclas Control

Table 2.5 Control Mix Proportioning

\begin{tabular}{|c|c|c|c|c|c|c|c|c|c|c|c|c|}
\hline \multirow{2}{*}{$\begin{array}{l}\text { Mezcla } \\
\text { Mixture }\end{array}$} & \multicolumn{7}{|c|}{ Materiales $/ \mathrm{M}$ aterial $\mathrm{sg} / \mathrm{m}^{3}$} & \multirow{2}{*}{$\begin{array}{l}a / c \\
w / c\end{array}$} & \multirow{2}{*}{$\begin{array}{l}\text { a/aglom } \\
\text { w/binder }\end{array}$} & \multirow{2}{*}{$\begin{array}{l}\text { Vpasta (I) } \\
\text { Vpaste (I) }\end{array}$} & \multirow{2}{*}{$\begin{array}{l}\text { a/finos (en vol.) } \\
\text { w/fines (in vol.) }\end{array}$} & \multirow[b]{2}{*}{ As $(\mathrm{cm})$} \\
\hline & $\begin{array}{l}\text { Cemento } \\
\text { Cement }\end{array}$ & $\begin{array}{l}\text { Cal } \\
\text { Lime }\end{array}$ & $\begin{array}{l}\text { Zeolita } \\
\text { Zeolite }\end{array}$ & $\begin{array}{l}\text { Arena } \\
\text { Sand }\end{array}$ & $\begin{array}{l}\text { Granito } \\
\text { Granite }\end{array}$ & $\begin{array}{l}\text { Agua } \\
\text { Water }\end{array}$ & N200 & & & & & \\
\hline Control & 395.20 & 0.0 & 0.0 & 860.55 & 924.76 & 158.37 & 4.74 & 0.40 & 0.40 & 283.83 & 1.26 & 13 \\
\hline
\end{tabular}

Según se aprecia en la Figura 2.2, el diseño de la mezcla control, satisface el cumplimiento de las exigencias de resistencia a la compresión a los 28 días para la cual fue diseñada.

\subsubsection{Fabricación M ezclas Experimentales. Etapa II}

Las mezclas experimentales correspondientes a esta etapa, fueron obtenidas a partir de hacer variar en la Mezcla Control, las cantidades de CPO por adición mineral cal- zeolita (ACZ), evaluando los niveles $10 \%$, $20 \%, 30 \%$ y $40 \%$ de sustitución en masa, manteniendo constante el resto de los constituyentes. El agua fue controlada hasta obtener valores de asentamiento de $12 \pm 1 \mathrm{~cm}$. medidos en el Cono de Abrams. Incorporación de los constituyentes de la adición mineral de forma independiente en proporción $20 \%$ de cal y $80 \%$ de zeolita en masa. Determinación de la resistencia a la compresión de cada mezcla a los 3, 7, 28 y 60 días.

El límite de sustitución de CPO/ACZ y con ello el volumen de pasta $\left(\mathrm{V}_{\text {pasta }}\right)$ a utilizar en la Etapa III, Io definirá la mezcla experimental cuyo nivel de sustitución ofrezca valores de resistencia a la compresión a los 28 días que no difieran significativamente al definido por la Mezcla Control. Así fueron obtenidos las dosificaciones y características de las mezclas de hormigón y los resultados de resistencia media a la compresión, tal como se muestran en la Tabla 2.6 y Figura 2.2.
In Figure 2.2 it can be appreciated that the control mix design fulfills the compressive strength requirements at 28 days, as it was designed.

\subsubsection{Manufacturing of Experimental Mixture. Step II}

The experimental mixtures concerning this step were obtained from the Control Mix variation, the amount of OPC by lime-zeolite mineral addition (LZA), the evaluation of levels $10 \%, 20 \%, 30 \%$ and $40 \%$ of mass substitution and maintaining constant the rest of the constituents. Water was controlled until obtaining slump values of $12 \pm 1 \mathrm{~cm}$ measured by the slump test. The addition of the constituents of the mineral addition was done independently, in proportion of $20 \%$ lime and $80 \%$ zeolite in mass. Compressive strength at 3, 7, 28 and 60 days of each mixture was measured.

The O PC/LZA substitution limit and the paste volume $\left(V_{\text {paste }}\right)$ that will be used in Step III, will be defined by the experimental mixture, whose substitution level offers compressive strength values at 28 days that is not significantly different from the one defined by the Control $M$ ix. In this way, the concrete mixture proportioning and characteristics were obtained, as well as the results of the mean compressive strength, as shown in Table 2.6 and Figure 2.2. 
Tabla 2.6 Características M ezclas Experimentales CPO /ACZ (Sustitución en masa) Table 2.6. Experimental O PC/LZA M ixture Characteristics (Substitution in mass)

\begin{tabular}{|c|c|c|c|c|c|c|c|c|c|c|c|c|}
\hline $20 \%$ & 131.09 & 15.65 & 62.61 & 852.20 & 915.79 & 157.53 & 4.68 & 0.50 & 0.40 & 290.60 & 1.18 & 11 \\
\hline $30 \%$ & 271.92 & 23.31 & 93.22 & 845.85 & 908.98 & 159.26 & 4.65 & 0.59 & 0.41 & 295.73 & 1.17 & 12 \\
\hline
\end{tabular}

El uso de la adición mineral cal- zeolita, influye en las características del hormigón en estado fresco. Como se aprecia en la Tabla 2.6 y tomando como referencia la mezcla Control, los volúmenes de pasta se ven incrementados, en la medida que crece el nivel de sustitución de las cantidades de CPO por ACZ, excepto para el $10 \%$, y en todos los casos, el volumen de pasta supera el volumen de vacíos entre los áridos de 263.8 litros. Estos incrementos del $V_{\text {pasta }}$ están relacionados con la elevación de la demanda de agua de amasado en la mezcla y con las diferencias de densidad entre la adición y el cemento.

El incremento en el volumen de pasta de la mezcla, trae aparejado la separación entre los agregados, disminuyendo así la fricción entre estos y como consecuencia las características reológicas (plasticidad, fluidez) de la mezcla, se mantienen con pocos cambios al igual que los consumo de agua, tal y como ocurre para los hormigones autocompactantes.

La disminución del volumen de pasta en la mezcla del $10 \%$ de sustitución, esta asociado a la acción combinada de la ACZ y el superplastificante, logrando para una mínima demanda de agua, obtener la trabajabilidad requerida. Trabajar con una cantidad constante de superplastificante en las mezclas, hace que el efecto dispersante tenga mayor acción en la mezcla con el $10 \%$ menos de cemento, además del efecto plastificante de la adición, aportado principalmente por la cal. Los efectos sobre la compacidad de la adición mineral cal- zeolita, justificarían los incrementos de resistencia en las primeras edades.

De los resultados mostrados en la Figura 2.2, puede ser apreciado la influencia del nivel de sustitución de CPO por ACZ en masa, sobre el comportamiento de la resistencia media a la compresión. Por encima del $30 \%$ de sustitución de CPO por ACZ en masa,
The use of lime-zeolite mineral addition produces an effect on the characteristics of fresh concrete. As it can be seen on Table 2.6, and considering as a reference the Control Mix, the paste volumes increases as the substitution level of the O PC by LZA increases, except for the $10 \%$, and in all cases, the paste volume exceeds the voids volume among aggregates of 263.8 liters. These increments of the Vpaste are related to the increase of mixture water demand and with the differences of density between the addition and the cement.

The paste volume increase in the mixture causes separation among the aggregates, thus decreasing friction among them and, as a consequence, the rheological characteristics (plasticity, fluidity) of the mixture experienced few changes as well as water consumption, similarly as with self-compacting concretes.

The paste volume decreasing in the mixture of $10 \%$ of substitution is associated to the combined action of the LZA and the superplastificizer, obtaining the required workability for a minimum demand of water. Working with a constant amount of superplasticizer in the mixture, causes the dispersion effect to have a greater action in the mixture with $10 \%$ less of cement, plus the plasticizing effect of the addition, mainly contributed by lime. The effects on the lime-zeolite mineral addition compaction would justify the increments on the early ages strengths.

From the results showed in Figure 2.2, the influence of the OPC replacement level by LZA by mass over compressive strength can appreciated. Over the $30 \%$ of LZA replacement by mass, 
disminuye drásticamente la resistencia a la compresión para todas las edades ensayadas. Lo anterior estará dado, por la disminución en el aporte de productos de reacción, que contribuyen a la resistencia de la matriz, principalmente del CPO.

Al comparar los valores medios de resistencia a la compresión entre las mezclas, se observa que no existen diferencias significativas a las edades de 28 y 60 días entre la mezcla control y el $30 \%$ de sustitución en masa, siendo significativa la diferencia para el resto de las comparaciones. Esta mezcla define entonces el límite de sustitución en masa de CPO por $\mathrm{ACZ}$, con $\mathrm{V}_{\text {pasta }}$ igual a 295.73 litros. compressive strength decreases strongly for all the ages. The preceding fact is given by the decrease in the reaction products contribution, which contributes to the matrix strength, mainly of the OPC.

When comparing the mean compressive strength values among mixtures, it can be observed that there are no great differences at ages of 28 and 60 days between the Control Mix and the $30 \%$ of substitution in mass; this difference is important for the rest of the comparisons. Thus, this mixture defines the substitution limit in mass for OPC by LZA, with $V_{\text {paste }}$ equal to 295.73 litres.

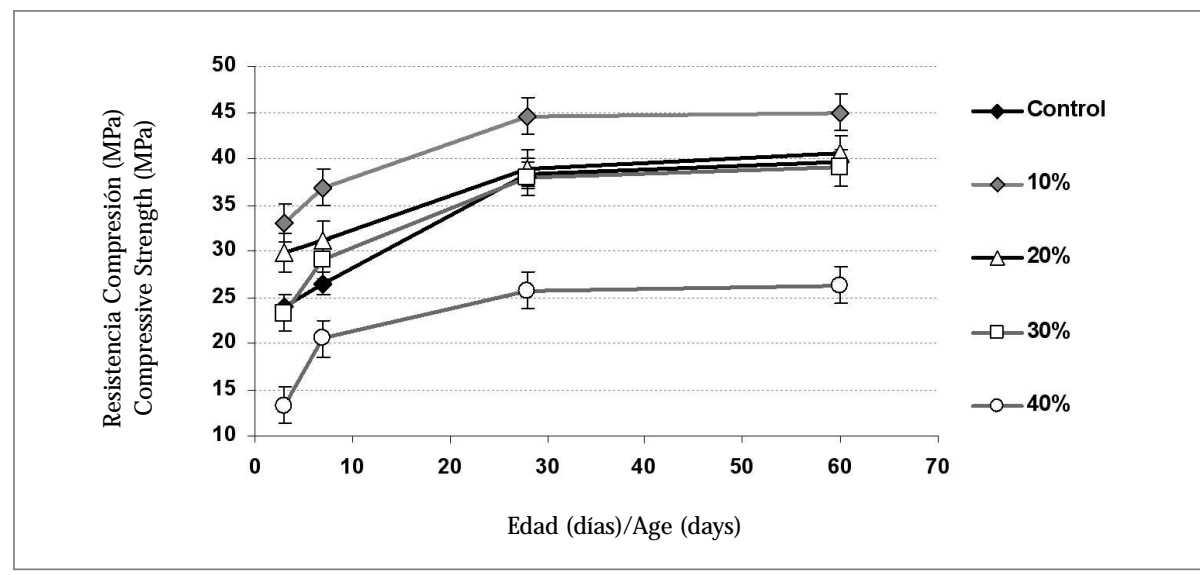

Figura 2.2 Comportamiento de la Resistencia media a la Compresión según nivel de sustitución de CPO/ACZ en masa Figure 2.2 Compressive Mean Strength Behaviour According to the Substitution Level of OPC by LZA in Mass

\subsubsection{Fabricación Mezclas Experimentales. Etapa III}

Para la determinación del límite de sustitución en volumen de CPO/ACZ en esta etapa, son variados en volumen ( $\beta$ ) las proporciones de CPO y ACZ dentro del volumen de pasta que define la mezcla del $30 \%$ de sustitución en masa. Esta mezcla se define a su vez como la mezcla del $37 \%$ de sustitución en Volumen, que en lo adelante Ilamaremosß-40. Manteniendo constante el volumen de pasta, los áridos, el agua y la cantidad de superplastificante, de forma tal que la relación en volumen agua/finos se mantiene constante, son variadas las proporciones en volumen de CPO y ACZ, evaluando los puntos correspondientes al $20 \%$ ( -20 ) y el $60 \%$ B-60) de sustitución en volumen como mezclas experimentales, elaboradas en condiciones similares a las mezclas de la etapa anterior. Así fueron obtenidas las dosificaciones (expresadas en unidades de masa) y los resultados de resistencia media a la compresión, tal como se muestran en la Tabla 2.7 y Figura 2.3.

\subsubsection{M anufacturing of Experimental Mixtures. Step III}

In order to determine the substitution limit in volume of OPC/LZA at this step, the OPC and LZA proportioning were varied in volume $\beta$ ) within the paste volume that defines the mix with a $30 \%$ of substitution by mass. In turn, this mixture is defined as the mix of $37 \%$ of substitution in volume, which henceforth will be called $\beta-40$. If the paste volume, aggregates, water and the amount of superplasticizer are maintained constant, in such a way that the water/fines ratio in volume is kept constant, the OPC and LZA proportioning in volume are varied, and the points that correspond to the $20 \% \beta(-20)$ and the $60 \% \beta-60$ ) of substitution in volume are evaluated as experimental mixtures, prepared in similar conditions to the preceding step mixtures. In this way, the proportioning (expressed in mass units) and mean compressive strength results were obtained, as can be seen in Table 2.7 and Figure 2.3. 
Tabla 2.7 D osificación M ezclas Experimentales CPO/ACZ (Sustitución en volumen) Table 2.7 O PC/LZA Experimental Mixture Proportioning (Substitution in volume)

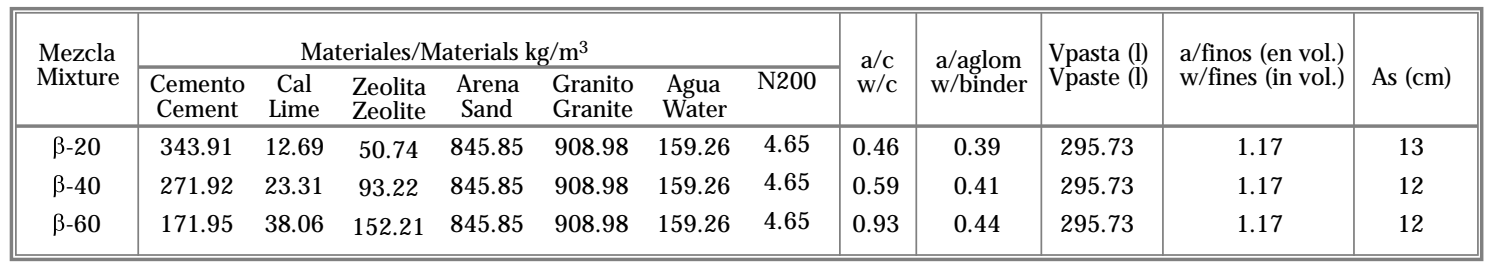

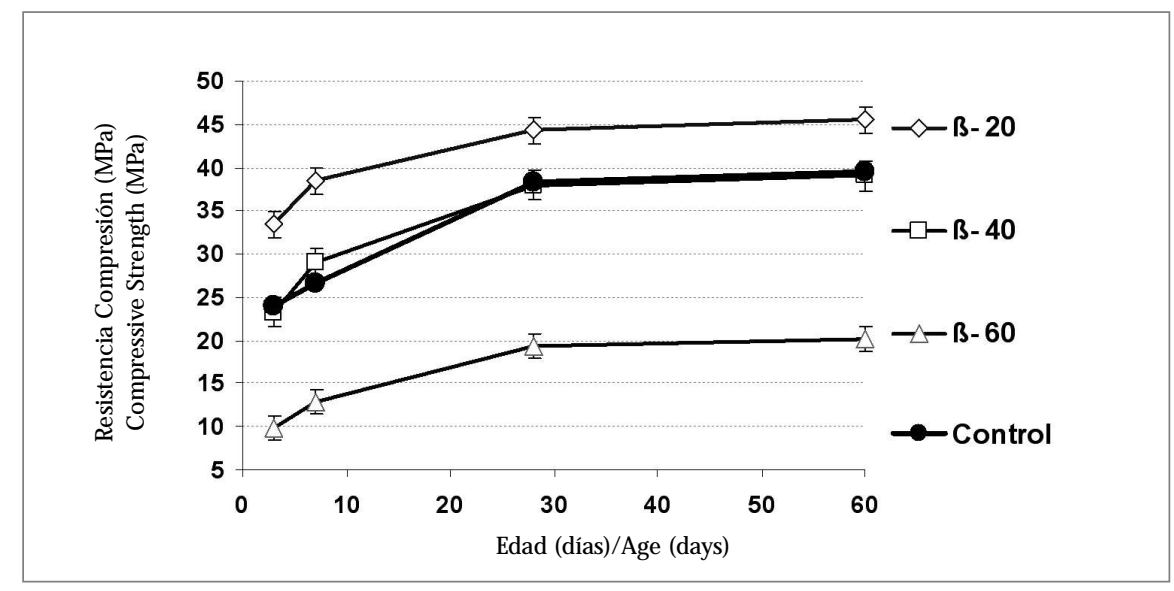

Figura 2.3 Comportamiento de la Resistencia media a la Compresión a las distintas edades Figure 2.3 Mean Compressive Strength at Different Ages

Las mezclas experimentales fabricadas en esta etapa, elaboradas con similares volúmenes de pasta y relación agua/finos constante, mantienen con poco cambios sus características reológicas de plasticidad y fluidez, medibles por la similitud en los valores de asentamientos obtenidos.

La variación en los niveles de sustitución de CPO por ACZ en volumen ( $($ ), dentro de un volumen de pasta constante, traen como consecuencia también, variación en los valores de resistencia obtenidos, aumentando ó disminuyendo en dependencia de los volúmenes de CPO presentes en la mezcla respectivamente, tal como se aprecia en la Figura 2.3. Los autores consideran que lo anterior esta dado por el aporte de cada aglomerante en la producción de sólidos, principalmente por los aportados en la hidratación del CPO, siendo significativas las diferencias en los valores medios de resistencia a la compresión al comparar los resultados entre las mezclas.

Del análisis de los resultados de resistencia media a la compresión obtenidos, se considera que utilizando hasta un $37 \%$ de sustitución en volumen de CPO por adición cal-zeolita es posible garantizar los valores de resistencia exigidos, definidos por la mezcla control.
In this step, the experimental mixtures prepared with similar volumes of paste and a constant water/fines ratio, maintain their rheological characteristics of plasticity and fluidity with few changes, and are measured by the similarity in the slump values obtained.

Variations in the substitution levels of OPC by LZA in volume $(\beta)$, within a constant paste volume, also carry out a variation on the strength values obtained, increasing or decreasing, depending on the O PC volumes present in the respective mixtures, as it can be appreciated in Figure 2.3. Authors consider that the preceding is given by the contribution of each binder on solids production, mainly for those shared out in the OPC hydration, and the differences in the mean compressive strength when compared with the results among mixtures are significant.

From the analysis of the mean compressive strength obtained, it is considered that using up a $37 \%$ of substitution in volume of O PC by lime-zeolite addition, it is possible to guarantee the required strength values defined by the Control Mix. 


\subsubsection{Análisis Durabilidad}

En la valoración del comportamiento de la durabilidad de las mezclas de hormigón en la Etapa III, incluyendo además la mezcla control, son evaluados los resultados obtenidos en el Ensayo Rápido de Resistencia a la Penetración de los Iones Cloruros según la ASTM 1202 "Standard Test M ethod for Electrical Indication of Concrete's Ability to Resist Chloride Ion Penetration" y la Determinación de la Profundidad de Carbonatación según NC 355 del 2004 “Determinación de la profundidad de carbonatación en hormigones endurecidos y puestos en servicio".

\subsubsection{Resistencia a la penetración de cloruros}

En el ensayo de resistencia a la penetración de los iones cloruros (ver Figura 2.4), fue determinada la carga pasada en Coulombs durante 6 horas, en muestras a la edad de un año. En función de la carga pasada en Coulombs, la normativa, hace una evaluación de la resistencia a la penetración de los iones cloruros en Alta (>4000), Moderada (2000 - 4000), Baja (1000 - 2000), Muy baja $(100-1000)$ y Despreciable $(<100)$. Los resultados obtenidos se muestran en la Figura 2.5.

\subsubsection{Durability Analysis}

When evaluating the behavior of concrete mixture durability in Step III, including the Control Mix, the results obtained in the Rapid Chloride Permeability Test (RCPT) are evaluated according to the ASTM 1202 "Standard Test Method for Electrical Indication of Concrete's Ability to Resist Chloride Ion Penetration" and carbonation depth determination according to the NC 355/2004 Carbonation Depth Determination on Hardened Concrete put In Service.

\subsubsection{Chloride Ion Penetration Resistance}

In the RCPT (see Figure 2.4), the charge passed is determined in Coulombs during 6 hours, in one year old samples. In function of the charge passed in Coulombs, normalization evaluates the chloride ion penetration resistance in: High (> 4000), Moderate (2000 - 4000), Low (1000 - 2000), Very low (100 - 1000) and Insignificant $(<100)$. The results obtained are showed in Figure 2.5.

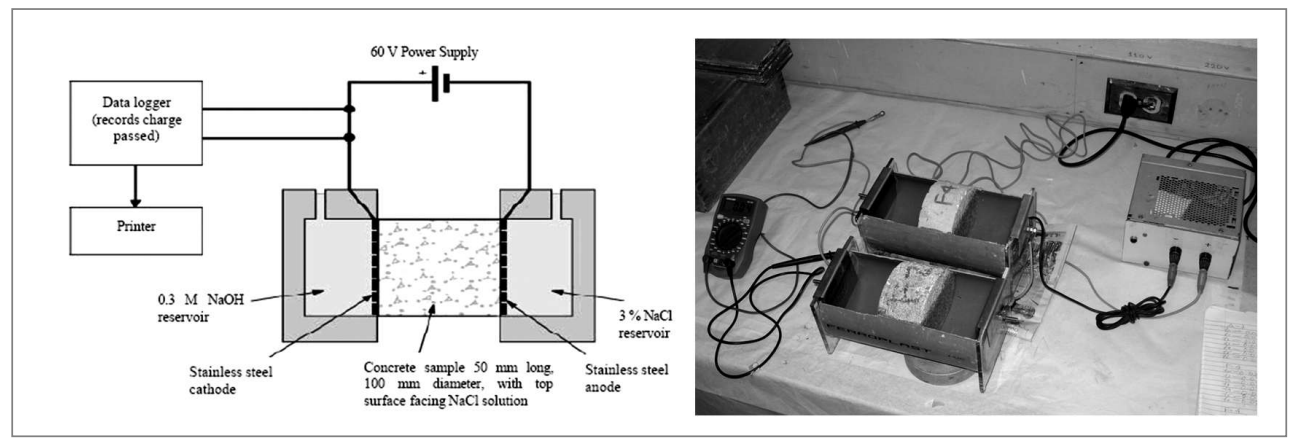

Figura 2.4 Set Ensayo Rápido de migración Ion cloruro, según AAH STO T277 (Izquierda); set utilizado por el autor (derecha) Figure 2.4 Set for Q uick Test of Chloride Ion Migration, according to AAHSTO T277(left); Set used by the author (right).
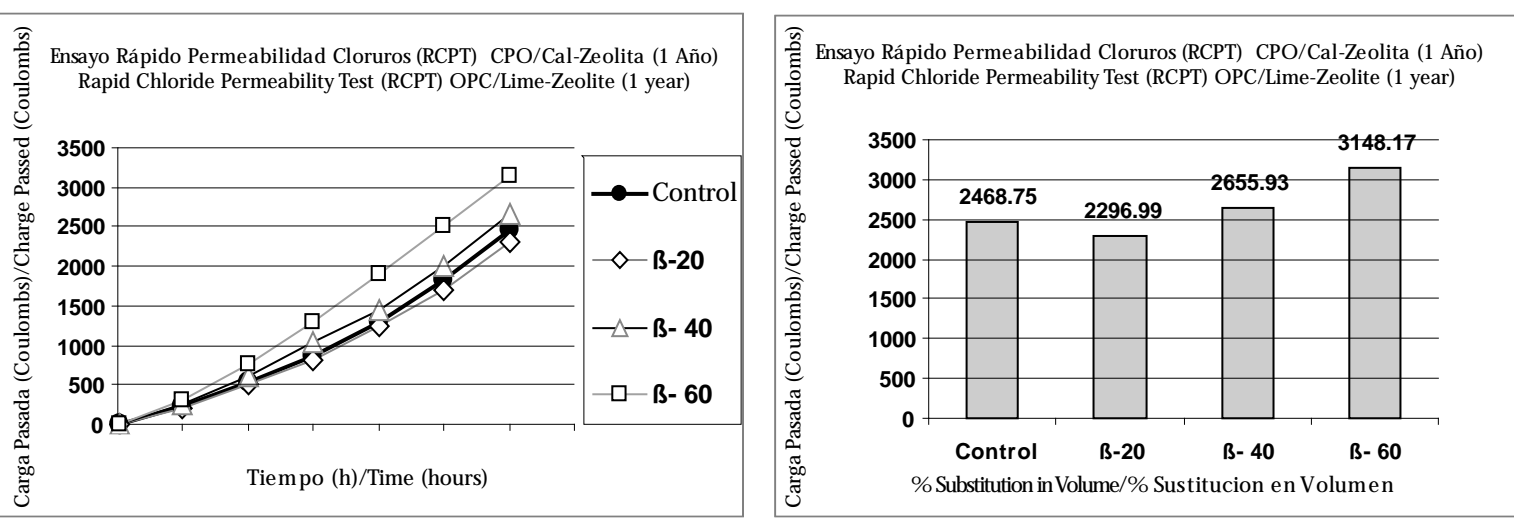

Figuras 2.5 Carga pasada en Coulombs a 1 Año. Resultados carga pasada por hora (izquierda). A las 6 horas (derecha) Figure 2.5 Charge Passed in Coulombs at 1 Year. Results of the Charge Passed by Hour (left); After 6 Hours (right) 
Al analizar el comportamiento del hormigón a ser penetrado por los iones cloruros, según parámetros que establece la ASTM 1202, se define penetrabilidad moderada para todas las mezclas.

De los resultados de la Figura 2.5, se aprecia disminución de la resistencia a la penetración de los iones cloruros, con el incremento del nivel de sustitución de CPO por ACZ. Sin embargo, al comparar los valores medios de carga pasada, entre los niveles $\beta-20$ y $\beta-40$, y de estos con la mezcla control, no existen diferencias significativas en la respuesta de las mezclas ante la penetración de los iones cloruros, lo cual podría estar dado por los cambios en la conectividad de la red de poros capilares en la matriz de hormigón, como consecuencia de las reacciones de hidratación, aportadas por la adición mineral, siendo este efecto ligeramente superior en el $20 \%$ de sustitución.

La mezcla correspondiente al $60 \%$ de sustitución, muestra los mayores valores de permeabilidad al paso de los iones cloruros. En esta mezcla, es de suponer la presencia de mayores cantidades de adiciones sin reaccionar, que estarían incidiendo con su alto poder de absorción en la disminución de la resistencia al paso de la corriente a través de la muestra.

Los resultados anteriores permiten afirmar, que al trabajar las mezclas dentro del volumen de pasta seleccionado como constante, hasta el 37\% $\beta$-40) de sustitución en volumen de CPO por ACZ, el comportamiento ante la penetración de los iones cloruro, resulta similar al ofrecido por la mezcla control, y por encima de este valor de sustitución, la corrosión del acero de refuerzo podría aparecer mas temprano que para el resto de las mezclas evaluadas.

\subsubsection{Profundidad de carbonatación}

Teniendo en cuenta que la carbonatación es un proceso lento en el tiempo, fue evaluada la acción del $\mathrm{CO}_{2}$ atmosférico en las muestras a la edad de 2 años. Los resultados obtenidos del ensayo de medición de la penetración de $\mathrm{CO}_{2}$, a través del cambio de coloración de la superficie de las muestras por rociado con fenolftaleina, se muestran en la Tabla 2.8 y Figura 2.6
When analyzing concrete resistance against chloride ion penetration, according to the parameters established by the ASTM C1202, a moderate penetrability for all the mixture is obtained.

In the results showed by Figure 2.5, an increase in chloride ion permeability, as replacement level of OPC by LZA increased, can be observed. N evertheless, when comparing the mean values of the charge passed, between levels $\beta-20$ and $\beta-40$, and of these with the Control Mix, it does not exist a significant difference in the mixture resistance against chloride ion penetration. This might be given by the changes in the connectivity of the capillary porous network in the concrete matrix as a consequence of hydration reactions, given by the mineral addition, being the effect slightly higher with the $20 \%$ of substitution.

The mixture with $60 \%$ replacement level shows higher values of chloride ion permeability. In this mixture, it can be assumed that the presence of higher amounts of unreacted additions may influence their high absorption power in decreasing the electric power pass resistance through the sample.

These results allow to confirm, that when working with the mixture within the selected paste volume as a constant, up to $37 \% \beta-40$ ) of substitution in volume of $O P C$ by LZA, the resistance against chloride ion penetration, results similar to that offered by the Control Mix; over this substitution value, steel reinforcement corrosion may appear earlier than for the rest of the evaluated mixtures.

\subsubsection{Carbonation depth}

Considering that carbonation is a long process through time, the atmospheric $\mathrm{CO}_{2}$ was evaluated in samples at the ages of 2 years. The results obtained in the measurement of $\mathrm{CO}_{2}$ penetration test through the surface coloration changes of samples by the phenolphthalein spray method are shown in Table 2.8 and Figure 2.6

Tabla 2.8 Penetración $\mathrm{CO}_{2}$ atmosférico Table 2.8 Penetration of Atmospheric $\mathrm{CO}_{2}$

\begin{tabular}{||l|c|c|c|c||}
\hline \hline Mezcla/Mixture & Control & $\beta-20$ & $\beta-40$ & $\beta-60$ \\
\hline Penetración $\mathrm{CO}_{2}(\mathrm{~mm}.) / \mathrm{CO}_{2}$ Penetration $(\mathrm{mm})$ & 0.89 & 1.65 & 1.72 & 5.53 \\
\hline
\end{tabular}


La mezcla Control, comparada con los resultados ofrecidos por las mezclas adicionadas, presenta los menores valores de penetración ante la acción del $\mathrm{CO}_{2}$ atmosférico. La presencia de la adición mineral, influye en la formación del frente de carbonatación, al incrementarse con el aumento de los niveles de sustitución de CPO por ACZ. Sin embargo, al comparar los valores medios de penetración definidos entre los niveles $\beta-20$ y $\beta-40$, y de estos con la mezcla control, no se definen diferencias significativamente entre los valores alcanzados. La mayor penetración alcanzada en $\beta$ - 60, podrían estar dada por la presencia de mayores cantidades de hidróxido de calcio en la adición, posible de reaccionar para formar el frente carbonatado.
The Control Mix, compared with the results from the mixture with additions, presents the lower penetration values facing the action of the atmospheric $\mathrm{CO}_{2}$. The mineral addition affects carbonation front formation, since the later increases with the increase on the substitution levels of OPC by LZA. N evertheless, when comparing the penetration mean values defined between levels $\beta$ 20 and $\beta-40$, and of these with the Control M ix, there are no significant differences defined among the values obtained. The higher penetration obtained in $\beta-60$ may be given by the presence of greater amounts of calcium hydroxide in the addition, that possibly may react to create the carbonation front.

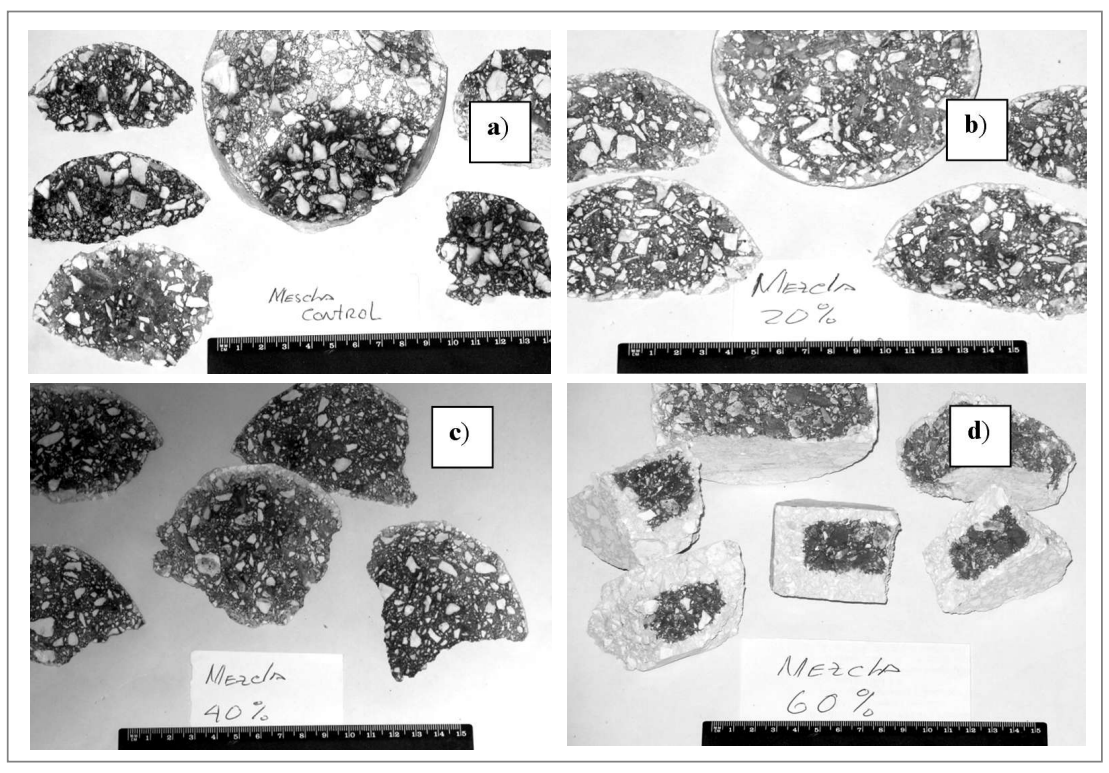

Figura 2.6 Avance del frente carbonatación, a) Mezcla Control; bß-20; c) B-40 y d) ß-60 Figure 2.6 Progress of Carbonation Front, a) Control Mix; bB-20; c) B-40 y d) B-60

Los resultados anteriores permiten afirmar, que al trabajar las mezclas dentro del volumen de pasta seleccionado como constante, hasta el $37 \% \quad \beta-40)$ de sustitución en volumen de CPO por $A C Z$, el comportamiento ante la penetración del $\mathrm{CO}_{2}$ atmosférico, resulta similar al ofrecido por la mezcla control, y por encima de este valor de sustitución, la despasivación del acero de refuerzo y con ello la corrosión, podría aparecer mas temprano que para el resto de las mezclas evaluadas.

Del análisis de los resultados en esta última etapa, la mezcla del $37 \%$ de sustitución en volumen de CPO por ACZ, no solo logra garantizar los requerimientos de resistencia a la compresión exigidos, si no también que lo hace con satisfactorios resultados ante la acción de los agentes agresivos.
The preceding results confirm that, when working the mixtures within the chosen paste volume as a constant, up to $37 \% \quad \beta-40$ ) of substitution in volume of OPC by LZA, the behavior facing the atmospheric $\mathrm{CO}_{2}$ penetration results similar to that offered by the Control Mix. Over this substitution value, the steel reinforcement depassivation and with it, corrosion, may appear earlier than for the rest of the evaluated mixtures.

From the analysis of the results of this final step, the mixture with $37 \%$ of substitution in volume of OPC by LZA, not only reached the compressive strength requirements but it also it gave satisfactory results facing the aggressive agents action. 


\section{Conclusiones}

1. Los resultados obtenidos, indican la influencia de la ACZ y del nivel de sustitución en volumen de CPO utilizado, en el comportamiento de la resistencia a la compresión y la durabilidad. Estos cambios se corresponden principalmente con la acción efectiva de la adición mineral en el aporte de productos hidratados, en el mejoramiento de la compacidad y en la disminución de la porosidad asociada a los capilares interconectados.

2. Utilizar hasta un $37 \%$ de sustitución en volumen de CPO por ACZ, en combinación con M APEFLUID N200, dentro un volumen de pasta constante, no solo logra satisfacer los requerimientos de resistencia a la compresión y trabajabilidad exigidos, si no también, satisfactorios resultados en la durabilidad, con reducciones notables en los consumos de cemento, sin afectar de forma significativa los requerimientos de la mezcla control.

3. Al evaluar diferentes mezclas de similares constituyentes y volumen de pasta, se precisa el intervalo exigido de la cantidad de cemento Pórtland necesario para obtener un hormigón dado, acorde a su aplicación y resistencia estructural, empleando una adición cal-zeolita, proveniente esta ultima de tobas zeolíticas, extraídas durante la producción industrial.

\section{Conclusions}

1. The results obtained show the influence of the LZA and that of the substitution level in volume of OPC used, in the behavior of the compressive strength and durability. These changes mainly agree with the effective action of the mineral addition in the contribution of hydrated products, in the compaction improvement and in the decrease of the porosity associated to the interconnected capillary pores.

2. The use up to a $37 \%$ of substitution in volume of OPC by LZA in combination with MAPEFLUID N200, within a constant paste volume, does not only satisfy the compressive strength requirements and workability demands, but it also obtains satisfactory results in durability, with good reductions in cement consumption and without affecting the requirements of the Control Mix.

3. When evaluating different mixtures with similar constituents and paste volume, it is necessary to consider the required interval for the amount of Portland cement necessary to obtain a given concrete, in agreement with its application and structural strength, using a limezeolite addition, obtained from the zeolitic tufas extracted during the industrial production.

\section{Referencias / References}

Aitcin Pierre- Claude (2000), "Cements of yesterday and today. Concrete of tomorrow", Cement \& Concrete Research Issue No. 9, Vol. 30, 1349-1359.

ASTM C 1202 (1997), Standard Test Method for Electrical Indication of Concrete's Ability to Resist Chloride Ion Penetration. 1997, ASTM

ASTM C 618- 03. (2003), Standard Specification for Coal Fly Ash and Raw or Calcined Natural Pozzolan for U se in Concrete. 2003, ASTM

Bornemann R. (2002), The role of powders in concrete. 6th international Symposium on utilization of high strength / high performance concrete. Leipzig

Brouwers H.J.H y Radix H.J. (2005), Self- Compacting Concrete: Theoretical and experimental study, Cement \& Concrete Research, 35 (2005), 2116-2136

Bentur y Mitchel (2008), Material performance lessons. Cement and Concrete Research, 38, 259-272 Jatuphon T. et al. (2005), Packing effect and pozzolanic reaction of fly ash in mortar. Cement and Concrete Research $351145-1151$ Martirena Hernández, J. F. (2004), U na alternativa ambientalmente compatible para disminuir el consumo de aglomerante de clinker de cemento Pórtland: el aglomerante cal-puzolana como adición mineral activa / José F. Martirena Hernández. -- Tesis de grado de Doctor en Ciencias; U CLV (Const.).

O "Reilly Diaz V. (1990), A. M étodo para diseñar mezclas de hormigón. Editorial Científico Técnica.

Mira P et al., (2002). Effect of lime putty addition on structural and durability properties of concrete. Cement and Concrete Research 32 683-689

Sebaibi Y. et al. (2004), A study of the viscosity of lime-cement paste: influence of the physico-chemical characteristics of lime, Construction $\&$ Building Materials, $18,653-660$.

Scrivener Karen L, y James Kirkpatrick R., (2008). Innovation in use and research on cementitious material. Cement and Concrete Research. 38 (2008) 128-136

NC 120 (2007), Hormigón Hidráulico. Especificaciones. NC

NC 251 (2005), Áridos para hormigones hidráulicos. Requisitos. NC

NC 355 (2004), Determinación de la profundidad de carbonatación en hormigones endurecidos y puestos en servicio. NC

Shi Y., et al. (2004), A study of the effect of fine mineral powders with distinct vitreous contents on the fluidity and rheological properties of concrete, Cement \& Concrete Research, 34, 1381-1387 